\title{
PHYTOTOXIC EFFECTOF SELECTED CRUDE PLANT EXTRACTS ON SOIL-BORNE FUNGI OF COMMON BEAN
}

\author{
B.O. OBONGOYA ${ }^{1}$, S.O. WAGAI ${ }^{2}$ and G. ODHIAMBO ${ }^{3}$ \\ ${ }^{1}$ Department of Resource Surveys and Remote Sensing, P.O. Box 47146-00100, Nairobi, Kenya \\ ${ }^{2,3}$ Department of Botany and Horticulture, Faculty of Science, Maseno University, \\ Private Bag, Maseno-Kenya \\ Corresponding author: obongoya@yahoo.com
}

(Received 6 July, 2009; accepted 5 January, 2010)

\begin{abstract}
Common bean (Phaseolus vulgaris L.) is an important food and cash crop particularly in Eastern, Southern and Great lake region. The efficacy of water based crude plant extracts of Neem (Azadirachta indica), Mexican marigold (Tagetes minuta), Tobacco (Nicotiana tobacum) and Peri-winkle (Vinca rosea) in controlling soil-borne fungi (Fusarium oxysporum Schl. f. sp. phaseoli) of common bean (Phaseolus vulgaris L.) was studied in the western province of Kenya. Thirty farms were used in the study carried out in August-September 2005 and March-June 2006. Broth microdilution method was used to determine minimum inhibitory concentration (MIC). All crude plant extracts controlled Fusarium yellows with varying efficacy. Neem extract was the most effective, while peri-winkle was the least. Wilt incidence was not affected by dosage regime. Neem is inhibitory to Fusarium growth at lower dosage than tobacco, Mexican marigold and peri-winkle with MIC ranging between 2.5 and $10.0 \mathrm{mg} \mathrm{ml}^{-1}$.
\end{abstract}

Key Words: Fusarium oxysporum, Kenya, Phaseolus vulgaris

\section{RÉSUMÉ}

Le haricot commun (Phaseolus vulgaris L.) est un important aliment et culture de rente, particulièrement dans la région Est, Sud et des Grands lacs. L'efficacité de l'eau extraite du Neem (Azadirachta indica), du marigold Mexicain (Tagetes minuta), du tabac (Nicotiana tobacum) et du Peri-Winkle (Vinca rosea) dans le contrôle de la maladie de champignon qui se transmit par le sol (Fusarium oxysporum Schl. f. sp. phaseoli), affectant le haricot commun (Phaseolus vulgaris L.) a été étudiée dans la province occidentale du Kenya. Cette étude a été conduite dans trente fermes, du mois d'Août en Septembre 2005 et de Mars en Juin 2006, et la méthode à bouillon microdiluée a été utilisée pour déterminer la concentration minimale inhibitrice (CMI). A un degré varié, tous les extraits bruts de plantes contrôlaient le Fusarium jaune et l'extraît du Neem a été marqué par une action la plus efficace que celle du peri-winkle. Alors que l'incidence du mildiou n'a pas été affectée par le regime posologique, il a été de même trouvé que Neem inhibe la croissance du fusarium à de doses plus faibles que celles du tabac, du Marigot mexicain et du peri-winkle avec un MIC variant entre 2.5 et $10.0 \mathrm{mg} \mathrm{l}^{-1}$.

Mots Clés: Fusarium oxysporum, Kenya, Phaseolus vulgaris

\section{INTRODUCTION}

Common bean (Phaseolus vulgaris L.) is an important food and cash crop particularly in the
Eastern, Southern and Great lake region. It, however, suffers from many soil-borne fungal diseases (Muchwezi-Mukiibi et al., 2001). It is considered the second most important source of 
human dietary protein and third most important source of calories after maize and cassava (Pachico, 1993). Common bean is grown by more than $90 \%$ of the population worldwide, mostly by small scale farmers for home consumption, with some surplus for sale (Janick, 1981).

A survey done in the central province of Kenya in 1980 revealed a high percentage incidence of soil-borne Fusarium yellows in all districts where beans were grown, but most seriously in Muranga and Kiambu where significant reductions in yields occured (Mutitu, 1989). In western Kenya, the incidence was high in Busia, Vihiga and Kakamega (DAO, 2004). Diseases such as Anthracnose, angular leaf spot, bean rust, bean scab, Sclerotinia rot and common bean mosaic virus are some of the important bean diseases that have received attention; but little has been done to control Fusarium yellows caused by Fusarium oxysporum Schl. f. sp. phaseoli.

Economical yield losses due to F. oxysporum Schl. f. sp. phaseoli have been reported in Colorado (Schwartz and McMillan, 1989), Egypt (El-Abyad et al., 1993), Colombia (Rusucu et al., 1997), Brazil (Pastor-Corrales and Abawi, 1987), Central Africa (Buruchara and Camacho, 2000) and Kenya (Mutitu, 1989). Synthetic chemical fungicides are being used successfully for control of F. oxysporum Schl. f. sp. phaseoli, but indiscriminate use of these chemicals has led to development of fungicide resistance and more importantly, environmental pollution, posing a potential risk to animal and human health (Lyon et al., 1995).

The major set back in the control of Fusarium oxysporum Schl. f. sp. phaseoli in the study area has been low per capita income; with household poverty incidence among subsistence farmers in the district being $68.2 \%$, even though it is classified as high potential zone in terms of Agricultural productivity (Ayako and Musambayi, 1997). This situation has hindered small-scale subsistence farmers acquiring synthetic chemicals to control fungal infection of beans. This scenario, therefore, calls for alternative approaches to the control of soil borne pathogens. The approach needs to be economically feasible and ecofriendly to increase yield of common bean. This study aimed at evaluating the phytotoxic activity of four locally available plant species in controlling Fusarium oxysporum Schl. f. sp. phaseoli infestation in field.

\section{MATERIALS AND METHODS}

The study was conducted in Busia district in the western province of Kenya, during two rainy seasons, namely August-September 2005 and March-June 2006. Thirty farms in six divisions, namely, Busia municipality, Budalangi, Matayos, Funyula, Nambale and Butula were used for the on-farm trials. The district receives $1150 \mathrm{~mm}$ of rainfall annually and experiences a mean maximum temperature of $26{ }^{\circ} \mathrm{C}$ and a minimum of $16^{\circ} \mathrm{C}$ (DAO, 2006).

Pathogen identification. Five plants were uprooted from each of the 30 surveyed farms and dried at room temperature $\left(22^{\circ} \pm 2^{\circ} \mathrm{C}\right)$ in a plant press for 5 days to facilitate isolation experiments. Isolations of the diseased plant specimens were done in a laboratory. Diseased plant specimens were sliced into pieces from reddish brown lesions on the hypocotyls and placed in sodium hypochlorite $(0.35 \%)$ solution for 3 minutes. The pieces were picked using a pair of sterile forceps, blotted dry and placed in 5 Potato Dextrose Agar (PDA) plates then incubated for 2 days at room temperature $\left(22^{\circ} \pm 2^{\circ} \mathrm{C}\right)$. Five to ten $\mathrm{ml}$ of sterile water was placed into each plate with pure culture of Fusarium oxysporum. The surface fungus was gently rubbed with a bent blunt glass-rod to remove the spores and contents emptied into the beaker.

The procedure was repeated with all pure cultures and contents emptied in same beaker. Spore suspension concentration was determined using hemacytometer. Subcultures were identified and described. The spore suspension was filtered using Muslin cloth and used to inoculate PDA slants. PDA slants in Mcartney bottles loosely screwed with caps fitted with an inner rubber lining and sterilised by autoclaving at $121^{\circ} \mathrm{C}$ at one bar gauge pressure $\left(10 \mathrm{~N} \mathrm{~m}^{-2}\right)$ for 15 minutes. The bottles were then left to air cool for 5 minutes at room temperature. The suspension was then placed in a slanting position. Forming a sloping medium surface was used to subculture pure 
Fusarium oxysporum fungus. Pure subculture was allowed to grow for 10 days. To induce conidiation of Fusarium oxysporum Schl. f. sp. phaseoli, carnation leaf agar (CLA) media was used (Togawa, 1992). For microscopic observation, Fusarium was grown on CLA at $25^{\circ} \mathrm{C}$ for 5 days, and agar blocks ( $\sim 2 \times 2 \mathrm{~mm})$ containing fungal propagules were cut out from the media. They were attached onto specimen stubs, frozen in liquid nitrogen, and observed with a scanning microscope (S-4000, Hitachi, Ibaraki, Japan) after gold coating.

Source of plant material. Azadirachta indica, Tagetes minuta, Nicotiana tobacum and Vinca rosea were collected from Budalangi and Butula areas of Busia district. Taxonomic authentification of plant specimens was performed by taxonomist at the Department of Botany -Herbarium and Botanic Garden, Maseno University, Kenya.

Screening for phytotoxic activities. Twenty grammes of freshly plucked leaves, flowers, seeds or stem of the four test plants were used. Individual or combinations of plant parts were crushed in a pestle and mortar with the help of 10-20 g of sterilised sand, which facilitated crushing. Crushed parts were filtered from the leaf juices. The juices were then centrifuged and supernatant were diluted as follows. Five dilutions were prepared: 10, 20, 30, 40 and 50\%.

A mixture of $3 \mathrm{ml}$ of 6-8 days old fungal spores $\left(2.5 \times 10^{6}\right.$ spores $\left.\mathrm{ml}^{-1}\right)$ and $5 \mathrm{ml}$ of the plant extracts and controls (Benomyl 1 and tap water) were prepared.

Sterilised inoculating needle was used to thoroughly stir the mixture. The resultant mixture (fungal spores and extract or control) was poured in 3mm diameter well in PDA plate and left for 6 hours (at room temperature) to allow spore germinate. The length of the germinated haustoria of Fusarium was scored as ( 0 or + ) based on microscopic observations. The above method was also applied for each of treatment of different dilutions.

Preparation of crude plant extracts. Crude plant extracts evaluated were obtained from Azadirachta indica, Tagetes minuta, Nicotiana tobacum and Vinca rosea. Benomyl 1 was used as + ve control. Crude extracts from single plants were prepared by mixing $1 \mathrm{~kg}$ of pounded leaves and/or seeds and/or flowers and/or twigs, then mixed in 1 litre of distilled water.

Individual plant extracts were filtered using sieves made of fine cloth mesh to yield 'concentrated' spray formulations. The 'concentrated' extracts were diluted in 4 litres of distilled water prior to application (Agona et al., 2001). Vinca rosea was prepared by adding a proportion of $1 \mathrm{~g}$ (approx. 1 teaspoonful) of ovendried plant material to $1 \mathrm{ml}$ of sterile distilled water (Narain and Satapathy, 1977). The control was the bean sprayed with Benomyl 1 (2.5 $\left.\mathrm{g} \mathrm{l}^{-1}\right)$ and distilled water. The leaves, flowers, seeds and twigs were used due to the fact that they contain high levels of active ingredients needed for pathogen control (Narain and Satapathy, 1977; Vyas et al., 1999; Tomova et al., 2005).

Crude plant extracts application. First spraying of crude plant extracts commenced upon appearance of $>30 \%$ wilt symptoms, based on disease severity scale $0-4(0=$ no symptoms; $1=1-33 \%$ foliage affected; $2=34-66 \%$ foliage affected; $3=67-100 \%$ foliage affected; $4=$ dead plant), (Bejarano-Alcázar et al., 1996) on the control. Spraying was done once a week and continued to second month (Pod forming stage). The application rate was 1000 and $2000 \mathrm{~g}^{-1}$ for four plant extracts; 2.5 and $5 \mathrm{~g}^{-1}$ for Benomyl 1 . Spraying was done using hand sprayer (ElHassan and Gowen, 2006).

Minimum inhibition concentration. The minimum inhibitory concentration (MIC) of the formulations against Fusarium yellows were determined using the broth microdilution method (Marchetti et al., 2000). The formulations were serially diluted with distilled water to prepare the solutions, with a series of concentrations ranging from 0.5 to $10 \mathrm{mg} \mathrm{ml}^{-1}$ per testing well. After shaking, $4 \mathrm{ml}$ of the antifungal agent solutions were added to the wells of 360-well plates. The suspension of $F$. oxysporum was adjusted to $2.5 \times 10^{6}$ spores $\mathrm{ml}^{-1}$ and then $5 \mathrm{ml}$ were added to the individual wells of four treatments and controls (Benomyl 1 and distilled water). The mixture was incubated at $24-28^{\circ} \mathrm{C}$. MIC is the lowest concentration that completely inhibited 
visible fungal growth in the wells after $72 \mathrm{hr}$ of incubation on observing under compound microscope (Mutitu, 1989). Each treatment was performed in triplicate.

Participatory on-farm trials. Participatory OnFarm trials (POFT) was conducted on 30 farms. The layouts for POFT were based on modified paired-comparison trial approach. For each treatment, strips ran across with dimensions of $25 \mathrm{~m} \times 2.25 \mathrm{~m}$ and replicated 3 times, comprising of 2 bean rows and 2 maize rows; the strips were separated from each other with a buffer strip. In each treatment strip, 1 bean row spacing was subjected to normal dosage and the other double dosage. Intrastrip buffer zones constituted maize row between the two bean strips.

This approach was chosen based on fact that it eliminates field variability effect. POFT experiment was set up based on randomised block design (RBD). Replications were randomised so as to avoid biasing effects that are not anticipated. Three small Rose coco bean seeds were sown at a spacing of $75 \mathrm{~cm}$ between row and $25 \mathrm{~cm}$ within the row. This bean variety was used in this study because it's the variety grown by approximately $90 \%$ of subsistence farmers in Busia district (DAO, 2004). The study was conducted under farmers' field scenario which was traditional subsistence farming condition with mixed cropping (Maize and beans only).

Treatments evaluated included Azadirachta indica, Nicotiana tobacum, Vinca rosea, Tagetes minuta, controls (Benomyl 1 and tap water).

Sampling procedure. Two bean rows of $25 \mathrm{~m}$ per plot were used to determine the number of plants showing Fusarium yellows over time with spraying. Data were collected from 3 replications in each farm and an average value computed. The data were collected at 4, 6 and $8^{\text {th }}$ week of plant growth so as to show trend of plants recovery.

Statistical analysis. Analysis of variance (ANOVA) was performed on the data, using Genstat 8th Edition Statistical Program (Release 8.11, Lawes Agricultural Trust, Rothamsted Experimental Station, Harpenden, UK). The least significant difference (LSD) procedure for comparison of means was applied to separate means $(\mathrm{P}<0.05)$.

\section{RESULTS}

Table 1 shows results of incidence with spraying over 5 weeks period. Benomyl 1 significantly $(\mathrm{P}<0.05)$ reduced disease incidence in over all other tested treatments. Azadirachta indica performed better among all the plant extracts. It reduced the incidence by about $17 \%$ compared to Tagetes minuta, Nicotiana tobacum and Vinca rosea whose reduction ranged from 5.84-9.8\% considering distilled water as bench mark.

Dosage regime (normal/double) did not significantly $(\mathrm{P}>0.05)$ affect disease incidence in the field. All the four crude plant extracts controlled Fusarium yellows but with varying degrees of efficacy.

Fusarium wilt incidence at 4 week after planting was recorded to range between $28-31 \%$ (Fig. 1). Spraying with extracts commenced at the $4^{\text {th }}$ week of growth and the incidence significantly reduced at $8^{\text {th }}$ week to lowest level of $10 \%$ as seen in Azadirachta indica. Dosage regime (normal/double) did not significantly $(\mathrm{P}>0.05)$ affect disease incidence in the field.

Plant extracts screening for fungal activity. Data for growth of $F$. oxysporum under control, conventional chemical (Benomyl 1) and crude plant extract treatments are presented in Table 2. The effects of crude plant extracts of $F$. oxysporum varied widely in the following order:

Tagetes minuta. This inhibited the germination of conidia of Fusarium. The inhibition was effective at higher concentrations (length of haustoria is $2-3 \mathrm{~mm}$ ) but less effective at lower concentrations (length of haustoria was 5-7 mm). Azadirachta indica significantly inhibited development and growth of conidia at higher concentrations (length of haustoria is 1-2 mm). Inhibition was also recorded against Fusarium at lower concentrations. Vinca rosea controlled the growth of Fusarium at a higher concentration (length of haustoria is 2-3 mm) but had no much effect in controlling Fusarium at lower concentrations (length of haustoria is 7-12 mm). 
Nicotiana tobacum did not play any major role in checking the germination of conidia of Fusarium (length of haustoria is 3-5 mm). Benomyl 1 (+ ve control) completely inhibited the generation of conidia of Fusarium at low concentrations. Water (-ve control) completely did not inhibit the generation and germination of conidia (length of haustoria is $7-12 \mathrm{~mm}$ ).

TABLE 1. Fusarium yellows incidence (\%) for five weeks

\begin{tabular}{lcc}
\hline Treatment & $\begin{array}{c}\text { Dosage } \\
\left(\mathrm{g}^{-1}\right)\end{array}$ & $\begin{array}{c}\text { Wilt } \\
\text { incidence (\%) }\end{array}$ \\
\hline Nicotiana tobacum & 1000 & $24.6 \pm 2.2$ \\
& 2000 & $21.6 \pm 1.3$ \\
Vinca rosea & 1000 & $21.2 \pm 0.9$ \\
& 2000 & $20.7 \pm 0.7$ \\
Tagetes minuta & 1000 & $20.7 \pm 0.7$ \\
& 2000 & $21.6 \pm 0.9$ \\
Azadirachta indica & 1000 & $13.2 \pm 0.7$ \\
& 2000 & $15.1 \pm 0.7$ \\
Benomyl 1(+ve control) & 2.5 & $10.7 \pm 0.3$ \\
& 5 & $11.7 \pm 0.3$ \\
Water (-ve control) & 500 & $30.5 \pm 2.3$ \\
LSD & & 4.38 \\
\hline
\end{tabular}

Minimum inhibitory concentration (MIC). Benomyl 1 exhibited the strongest inhibition against Fusarium yellows with MIC of 1.0 $\mathrm{mg} \mathrm{ml}^{-1}$ (Table 3). Fungicidal activity against Fusarium yellows by Tagetes minuta and Vinca rosea was rated as $5 \cdot 0 \mathrm{mg} \mathrm{ml}^{-1}$ compared to $10 \mathrm{mg} \mathrm{ml}^{-1}$ for Nicotiana tobacum.

The MIC of Azadirachta indica, $2.5 \mathrm{mg} \mathrm{ml}^{-1}$, was higher than that of Benomyl 1, It was however, much lower than in all other plant extracts.

\section{DISCUSSION}

Azadirachta indica formulation gave a significant reduction in wilt incidence compared to the other three crude plant extracts formulations (Table 1). Application of Neem as spray is systemically translocated into the plant hence inhibiting mycelial growth in the vascular system (Gupta et al., 1999; Vyas et al., 1999). Based on this research, it is evident that Neem can be used to control Fusarium yellows disease on farms, given its significantly inhibited development and growth of conidia at higher concentrations as well as at lower concentration. Further it is a natural botanical pesticide with a low risk of toxicity to humans and animals; it can be one of the important plant protection agents in integrated

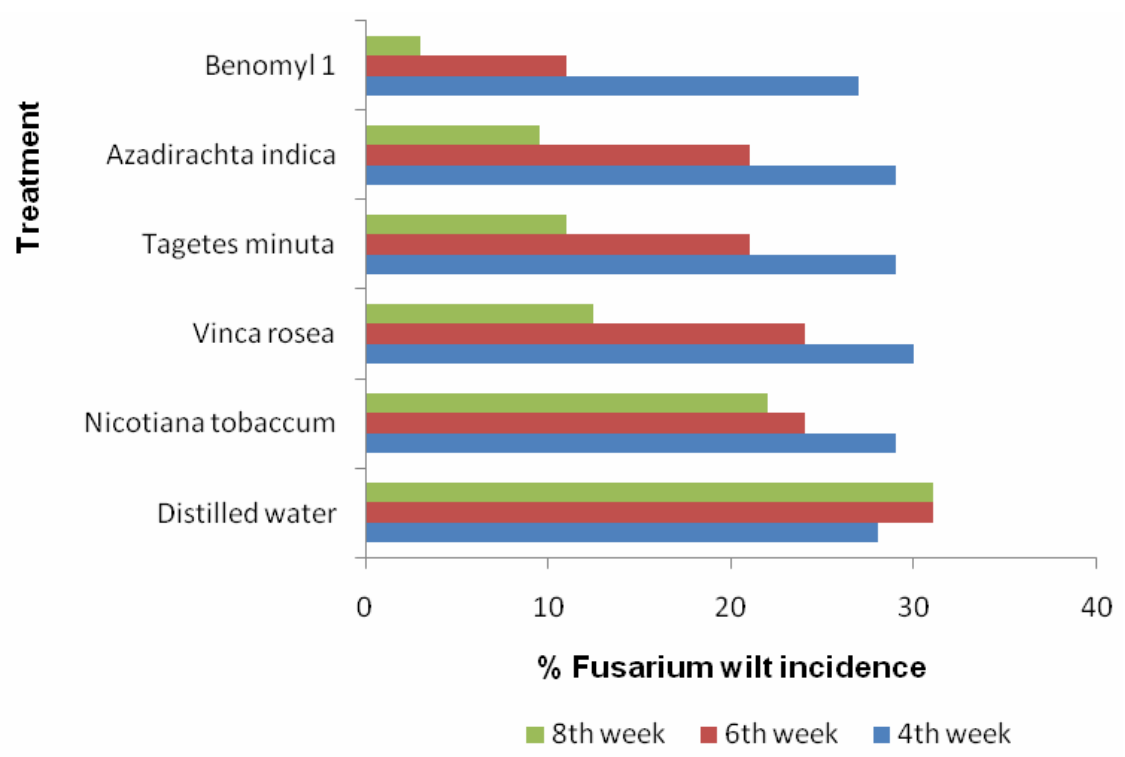

Figure 1. Fusarium yellows incidence overtime with normal spraying regime in farmers fields during March-June 2006 season. 
TABLE 2. Treatments screening for phytotoxic activity

\begin{tabular}{|c|c|c|c|c|c|}
\hline \multirow[t]{2}{*}{ Treatment } & \multicolumn{5}{|c|}{ Dilution (\%) } \\
\hline & $10 \%$ & $20 \%$ & $30 \%$ & $40 \%$ & $50 \%$ \\
\hline Vinca rosea & ++ & +++ & ++++ & ++++ & ++++ \\
\hline Tagetes minuta & ++ & +++ & +++ & ++++ & +++ \\
\hline Azadirachta indica & + & ++ & ++ & ++ & ++ \\
\hline Nicotiana tobacum & +++ & +++ & ++++ & ++++ & ++++ \\
\hline Benomyl 1 (+ve control) & 0 & 0 & 0 & 0 & + \\
\hline $\begin{array}{l}\text { Distilled water (-ve control) } \\
+/ 0=\text { length of haustoria }\end{array}$ & +++++ & +++++ & +++++ & +++++ & ++++ \\
\hline
\end{tabular}

Legend: $<1 \mathrm{~mm}=0 ; 1-2 \mathrm{~mm}=+; 2-3 \mathrm{~mm}=++; 3-5 \mathrm{~mm}=+++; 5-7 \mathrm{~mm}=++++; 7-12 \mathrm{~mm}=+++++; 0=$ no length

pest management (IPM) programmes for the subsistence farmers.

Tagetes minuta performed better in controlling F. oxysporum but with lower efficacy in comparison to $A$. indica. Bioactive extracts from different Tagetes species have been shown to have insecticidal, nematicidal, and fungicidal properties. No previous reports on fungitoxic activity of $T$. minuta could be traced in literature; to date documented information on medicinal properties of T. minuta is on its use in pest control initiatives. This study has dealt with the phytotoxic activity of $T$. minuta.

Results from this study indicate T. minuta is promising botanical that can be utilised in control of Fusarium yellows, though inhibiting the germination of conidia of Fusarium at higher concentrations. Although no significant $(\mathrm{P}>0.05)$ difference among $T$. minuta and $V$. rosea against $F$. oxysporum were observed in wilt incidence, putting in consideration other evaluated parameter such as MIC; T. minuta can be rated superior to Vinca rosea.

$V$. rosea controlled $F$. oxysporum at a much higher concentration (MIC of $5.0 \mathrm{mg} \mathrm{ml}^{1}$ ) in comparison to A. indica and Benomyl 1 (Table 3). Vinca rosea has been documented to posses' fungitoxic characteristics and has been able to control (in-vivo) a number of fungi such as $H$. modulosum, S. rolfsii, Pestalotia sp and Colletotrichum $s p$ completely at $8 \mathrm{ml}$ extract; in contrast F. oxysporum and A. niger exhibited growth (Narain and Satapathy, 1977). Findings from this study concur with results of Narain and
TABLE 3. Minimum inhibitory concentration (MIC) of various treatments estimated by broth microdilution method

\begin{tabular}{lc}
\hline Treatment & MIC $^{1}($ mean \pm SE) \\
\hline Nicotiana tobacum & $10 \cdot 0$ \\
Tagetes minuta & $5 \cdot 0$ \\
Vinca rosea & $5 \cdot 0$ \\
Azadirachta indica & 2.5 \\
Benomyl 1 & 1.0 \\
LSD & 0.97 \\
\hline
\end{tabular}

$\mathrm{MIC}^{1}\left(\mathrm{mg} \mathrm{ml}^{-1}\right.$

Satapathy (1977) indicating that $V$. rosea may be possibly effective in-vivo as opposed in the field hence not a potential candidate for on-farm control of $F$. oxysporum.

This study show Nicotiana tobacum formulation does not significantly affect $F$. oxysporum when compared to distilled water (negative control). Little however is documented about its phytotoxic properties against plant pathogens, though it is known to be highly poisonous due to alkaloid nicotine, a powerful neurotoxin that is particularly harmful to insects. Research indicates tobacco has insecticidal activity that control Acanthoscelides obtectus Say (Coleoptera: Bruchidae) (Agona et al., 2001; Ofunya, 1989). Having not significantly differed with distilled water (negative control) in controlling Fusarium, tobacco is greatly limited as a candidate in management of Fusarium oxysporum Schl. f.sp phaseoli on farm. 


\section{CONCLUSION}

Participatory On Farm Trials (POFT) has shown that crude plant extracts are effective in controlling Fusarium oxysporum Schl. f.sp. phaseoli, with varying degree of efficacy. Spraying with crude extracts reduced the incidence of Fusarium in the field and also resulting in complete recovery of initially infected bean plants. Azadirachta indica and Tagetes minuta were found to be the highly effective plant extracts amongst test crude plant extracts. Besides inhibiting growth of Fusarium in vascular system of the plants they also resulted in low wilt incidence.

\section{ACKNOWLEDGEMENT}

Financial support for this study was provided by African Institute for Capacity Development (AICAD), Nairobi, Kenya contract No. AICAD/ $05 / \mathrm{C} / 21$, which the authors gratefully acknowledge.

\section{REFERENCES}

Agona, J.A., Owera-Odom, F., Kyamanywa, S., Silim-Nahdy, M. and Willson, H.R. 2001. Field management of bruchids on beans using selected phytochemicals, insecticides and entomopathogen. In: Proceedings of Integrated Pest Management Conference for Sub-Saharan Africa, Kampala-Uganda $8^{\text {th }}-12^{\text {th }}$ September 2000. 5:154-157.

Ayako, A.B. and Musambayi, K. 1997. Review of poverty in Kenya. Institute of Policy Analysis and Research (IPAR). Nairobi, Kenya.

Bejarano-Alcázar, J., Blanco-López, M.A., MeleroVara, J. M. and Jiménez-Díaz R.M. 1996. Etiology, importance, and distribution Verticillium wilt of cotton in Southern Spain. Plant Diseases 80:1233-1238.

Buruchara, R. A. and Camacho, L. 2000. Common bean reaction to Fusarium oxysporum $f$. sp. phaseoli, the cause of severe vascular wilt in Central Africa. Phytopathology 148:39-45.

DAO. 2004. District Agriculture Office. Busia district monthly Agricultural reports: January 2003-June 2004. DAO, Busia, Kenya.
DAO. 2006. District Agriculture Office. Busia district monthly Agricultural reports: January 2004-June 2006. DAO, Busia, Kenya.

El-Abyad, M. S., El-Sayed, M. A., El-Shanshoury, A. R. and El-Batanouny, N.H. 1993. Inhibitory effects of UV mutants of Streptomyces corchorus and Streptomyces spiroverticillatus on bean and banana wilt pathogens. Canadian Botanica 71:1080-1086.

El-Hassan, S. A. and Gowen, S. R. 2006. Formulation and Delivery of the Bacterial antagonist Bacillus subtilis for management of Lentil vascular wilt caused by Fusarium oxysporum f. sp. Lentil. Phytopathology 154: 148-155.

Gupta, P., Paul, M.S., Sharma, S.N. and Gupta, P. 1999. Studies on compatibility of white muscardine fungus Beauveria bassiana with some neem products. Indian Phytopathology 52: 278-280.

Janick, J. 1981. Plant Science: An introduction to world Crops. $3^{\text {rd }}$ Edition, W.H. Freeman and Company. New York, USA.

Kendrick, W.B. and Snyder, W.C. 1942. Fusarium oxysporum Schl.f. sp. phaseoli, Kendrick \& Snyder. Phytopathology 32:1010-1014.

Lyon, G.D., Beglinski, T. and Newton, A.C. 1995. Novel disease control compounds: the potential to 'immunise' plants against infection. Plant Pathology 44:407-427.

Marchetti, O., Moreillon, P., Glauser, M. P., Bille, J. and Sanglard, D. 2000. Potent synergism of the combination of fluconazole and cyclosporine in Candida albicans. Antimicrobial Agents and Chemotherapy 44: 2373-2381.

Muchwezi-Mukiibi, J., Kyamanywa, S. and Ogenga-Latigo, M.W. 2001. Damage-yield relationship and economic injury levels of pod-borers and pod sucking bugs on the common bean In: Proceedings of African Crop Science Conference 5:159 - 166.

Mutitu, E.W. 1989. Fusarium yellows of Beans caused by Fusarium oxysporum Schl.f.sp. phaseoli in Kenya. PhD. Thesis, University of Nairobi, Kenya. 233pp.

Narain, A. and Satapathy, J.N. 1977. Antifungal characteristics of Vinca rosea extracts. Indian Phytopathology 30:36-40. 
Ofunya, T.I. 1989. Use of wood ash, dry chilli pepper fruits and onion scale leaves for reducing Callosobruchus maculates (F) damage in cowpea seeds during storage. Journal of Agricultural Science, Cambridge 107:467-468.

Pachico, D. 1993. The demand for bean technology. In: Harry, G.. (Ed.), pp. 60-73. Trend in CIAT commodities 1993, CIAT. Cali, Colombia.

Pastor-Corrales, M. A. and Abawi, G. S. 1987. Reactions of selected bean germ plasm to infection by Fusarium oxysporum $f$. $s p$. phaseoli. Plant Diseases 71: 990-993.

Rusucu, G., R. Buruchara, A., M. Gatabazi, M. and Pastor-Corrales, A. 1997. Occurrence and distribution in Rwanda of soilborne fungi pathogenic to the common bean. Plant Diseases 81:445-449.
Schwartz, H. F. and McMillan, M. S. 1989. Occurrence of Fusarium wilt of beans in Colorado. Plant Diseases 73:518.

Togawa, M. 1992. Effect of sterilisation methods, plant varieties and leaf stages on conidia and perithecia formation in genus Fusarium in CLA-culture. Transactions of the Mycology Society of Japan 33:385-393.

Tomova, B. S., Waterhouse, J. S. and Doberski, J. 2005. The effect of fractionated Tagetes oil volatiles on aphid reproduction. Entomologia Experimentalis et Applicata 115:153-159.

Vyas, B.N., Ganesan, S., Raman, K., Godrej, N.B. and Mistry, K.B. 1999. Effects of three plant extracts and achook: a commercial neem formulation on growth and development of three noctuid pests. In: Singh, R.P. and Saxena, R.C. (Eds.). Azadirachta Indica A. Juss. Oxford and IBH Publishing, New Delhi, India. pp. 103-109. 